\title{
Impacting the Community through a Sophomore Design Experience
}

\author{
Robert L. Nagel \\ Assistant Professor, Department of Engineering \\ James Madison University \\ Harrisonburg, VA 22807 \\ nagelrl@jmu.edu \\ Jacquelyn K. Nagel \\ Assistant Professor, Department of Engineering \\ James Madison University \\ Harrisonburg, VA 22807 \\ nageljk@jmu.edu
}

\author{
Kyle G. Gipson \\ Assistant Professor, Department of Engineering \\ James Madison University \\ Harrisonburg, VA 22807 \\ gipsonkg@jmu.edu \\ Thomas Moran \\ Associate Professor, Department of Kinesiology \\ James Madison University \\ Harrisonburg, VA 22807 \\ morante@jmu.edu
}

\begin{abstract}
Cornerstone design at James Madison University is a two-semester, client-based service learning project. Each year, sophomore engineering students work to design human-powered vehicles for a community member with needs very different from their own as a result of cerebral palsy. This paper provides a reflection of the fifth iteration (2013-2014) of this year-long sophomore design experience with the overarching goal to provide a transferable model such that other engineering programs may learn from our lessons and develop their own service learning experience. The reflection contained in this paper was catalyzed through participation in the National Science Foundation-funded Integrating Design and Community Engagement within the Curriculum Workshop hosted at Purdue University from June 19-20, 2014. In addition to reflection on the course, the paper provides insight into course coordination and assessment, and lessons learned over the past five years.
\end{abstract}

Index Terms - cornerstone design, engineering design, service learning

\section{INTRODUCTION}

Consider the following characteristics for a required engineering design course sequence: yearlong, immersive design project; frequent interactions with a community client; frequent interactions with partners both internal to the University and external; student team managed budget; studio and seminar spaces for creative and dirty work; formal presentations for conceptual design, alpha prototype, and beta prototype review; functional prototype expo and delivery; and a summer internship opportunity. On first review, this list may seem like the characteristics for an engineering capstone design experience; at James Madison University (JMU) it is the sophomore design experience - a cornerstone design course sequence taken by all engineering sophomores before entry into the two-year long engineering capstone design experience.

The sophomore design sequence is a two-course sequence generally taken during the student's second year within the Madison Engineering Department. The course sequence 
interweaves a year-long, client-based, design project with instruction in engineering design theory and methodology, engineering ethics, sustainable engineering design concepts, decision making, problem solving, and engineering design software. ${ }^{1-4}$ Throughout the year-long project, students interact with an actual client from the broader community with needs very different from their own to design an actual product that in some way meaningfully impacts the client's life. The project associated with the sophomore design sequence is meant to expose the students to an experience that transcends the classroom, and in the process, teach the students that they are part of a larger complex system. Through this project, students, as representatives of the University and the Department, see first hand how their decisions and actions as an engineer can (and likely will) influence individuals as members of society.
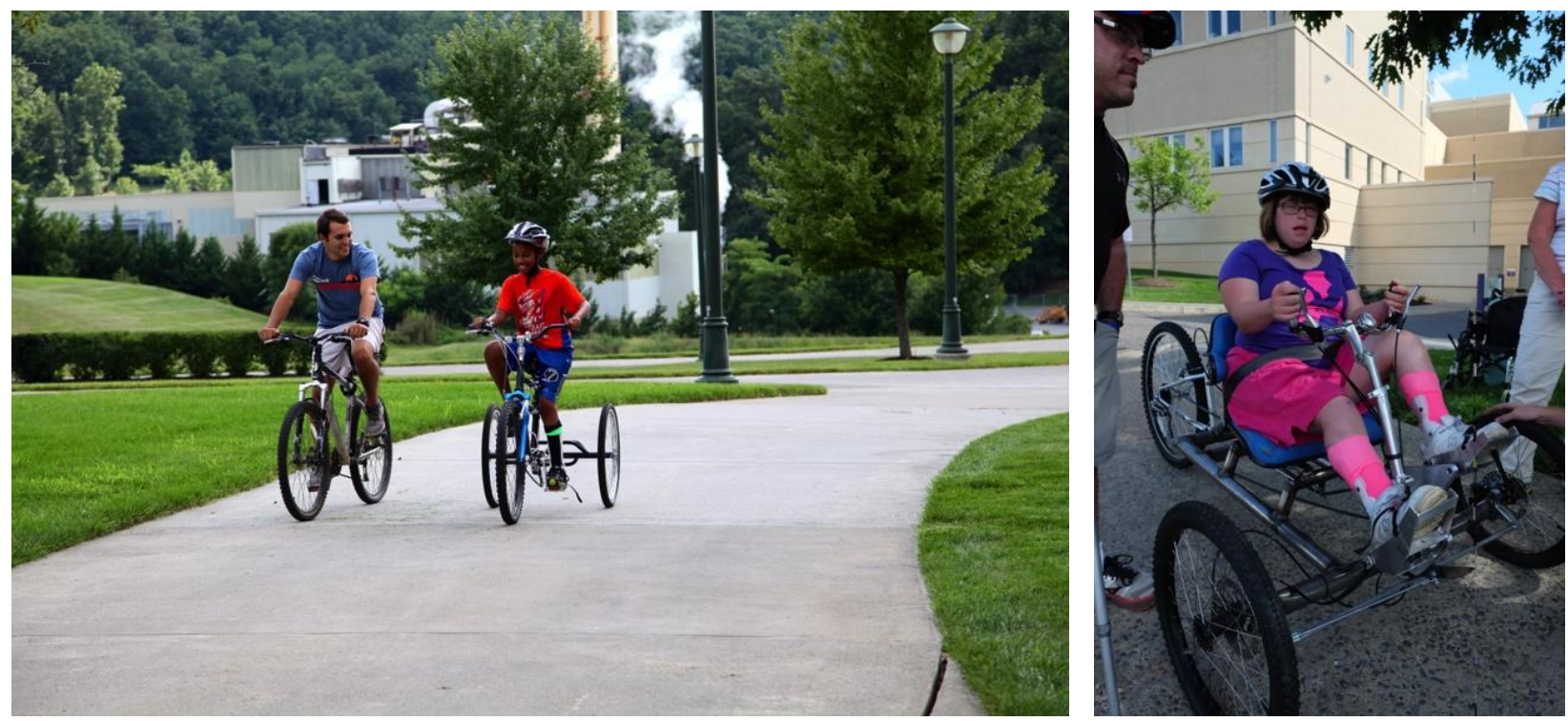

FIGURE 1

Example Human-Powered Vehicle Project Deliverables.

For the last five years, students have been designing human-powered vehicles (e.g., a bicycle) for individuals with cerebral palsy who otherwise are not able ride a bicycle such as those shown in Figure 1. Each year, while the theme of the project remains the same, the designs have varied greatly as each client's needs and requirements have been different. The two-course sophomore design experience began as a course design project focused on building a humanpowered vehicle for a client (JMU faculty member) during the Fall 2009 semester. ${ }^{3}$ The JMU faculty member approached the project's founding faculty members with the need for a humanpowered vehicle to exercise both his upper and lower body. Through the 2009-2010 academic year, the project's founding faculty members integrated design instruction and this real world design experience into the two-course, sophomore design experience.

Following that first year, the project has continued to grow. In the second year, the project focused on a community member outside the university who was a long time mentee of our first client. $^{1,2}$ Today, the project continues to focus on individuals from the local community; however, prior relationships have never been as strong as in the first and second years of the project. Growth has brought administrative procedures to help ensure that working relationships 
are established before the start of the project as well as course content changes to help ensure that a client surrogate is available in case the client becomes unavailable during the academic year.

This paper provides a reflection of the fifth iteration (academic year 2013-2014 with the syllabi located in the Appendix) of this year-long sophomore design experience through the lens of the Learning Through Service Program Model Blueprint. ${ }^{5}$ The reflection contained herein was catalyzed through participation in the National Science Foundation-funded Integrating Design and Community Engagement within the Curriculum Workshop hosted at Purdue University from June 19-20, 2014. ${ }^{6}$ At the workshop, the Blueprint was presented as a service learning project development framework, but application of the Blueprint on existing service learning courses at JMU allowed for critical reflection toward course iteration. Using the structure of the Blueprint, while repetitive at times, provides a developmental and/or reflective framework for laying out another course-based, service learning project. We use the Blueprint to demonstrate key features, partnerships, and resources required to run a mandatory, one-year, curricular course such that others can understand how we have developed our course sequence. Our overarching goal is to provide a transferable model such that other engineering programs may learn from our lessons and develop their own service learning experience.

\section{Learning Through Service Program Model Blueprint}

The Learning Through Service Program Model Blueprint, based on the Business Model Generation, ${ }_{5}^{7}$ was published by Bielefeldt et al. at the 2013 ASEE Annual Conference and Exposition. ${ }^{5}$ The blueprint was generated to help course developers layout a service learning program. The Blueprint, is licensed by K.G. Paterson under the creative commons AttributionNoncommercial-ShareAlike 3.0 Unported License. Figure 2 provides a completed Blueprint for the sophomore design experience based on work started at the Integrating Design and Community Engagement within the Curriculum Workshop and completed back at JMU. The following sections, while described out of order from the Blueprint for clarity, map to each of the key sections of the Blueprint-Stakeholders, Value Proposition, Relationships, Channels, Key Activities, Resources, Partnerships, Values Streams: Costs and Outlays, and Value Streams: Returns. 


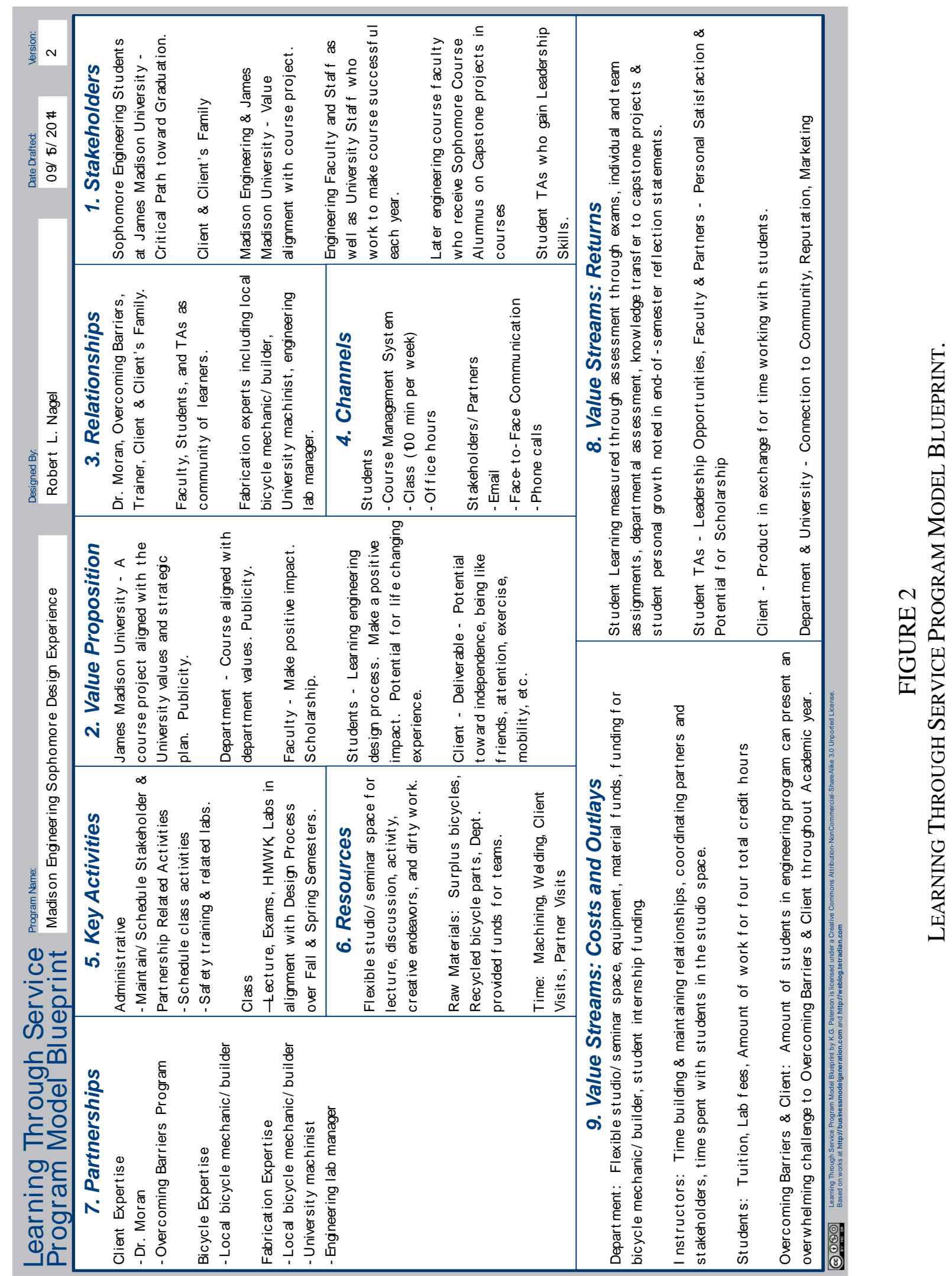




\section{Value Propositions}

The sophomore design course sequence is the cornerstone for the engineering program's sixcourse engineering design sequence, which is a critical path through the program. The sophomore design courses must be taken in sequence and as a pair. Sophomore Design 1 is only offered during the fall, and Sophomore Design 2 is only offered during the spring. As the cornerstone design experience, the sophomore design courses must set the tone and expectations for all further design courses that the students will complete. As a result, it is important that the sophomore design experience remains in alignment with the values and mission of the Department (Respect, Excellence, Collaboration, Generosity, and Learning) and the University (Academic Quality, Community, Diversity, Excellence, Integrity, and Student Focus). The Sophomore design experience is illustrated with all of the other engineering courses in the engineering curriculum in Table 1.

TABLE 1

The Sophomore Design Course Sequence Is CRITICAl PATH Through The JMU ENGINEERING PROGRAM.

\begin{tabular}{|c|c|c|c|c|c|c|c|}
\hline \multicolumn{2}{|c|}{ Freshman)Year } & \multicolumn{2}{|c|}{ Sophomore)Year } & \multicolumn{2}{|c|}{ Junior)Year } & \multicolumn{2}{|c|}{ Senior)Year } \\
\hline & & & & Thermo/Fluids.1 & Thermo/Fluids.2 & $\begin{array}{c}\text { Fundamentals.of. } \\
\text { Sustainable. } \\
\text { Engineering }\end{array}$ & $\begin{array}{l}\text { Social.and. } \\
\text { Community. } \\
\text { Sustainability }\end{array}$ \\
\hline \multirow[t]{3}{*}{$\begin{array}{l}\text { Engineering. } \\
\text { Choices }\end{array}$} & \multirow[t]{3}{*}{$\begin{array}{l}\text { Engineering. } \\
\text { Decisions }\end{array}$} & $\begin{array}{l}\text { Sophomore. } \\
\text { Design.1 }\end{array}$ & $\begin{array}{l}\text { Sophomore. } \\
\text { Design.2 }\end{array}$ & \begin{tabular}{|c|} 
Capstone.Design. \\
1
\end{tabular} & $\begin{array}{c}\text { Capstone.Design. } \\
2\end{array}$ & \begin{tabular}{|c|} 
Capstone.Design. \\
3
\end{tabular} & $\begin{array}{c}\text { Capstone.Design. } \\
4\end{array}$ \\
\hline & & & $\begin{array}{l}\text { Statics.\&. } \\
\text { Dynamics }\end{array}$ & $\begin{array}{l}\text { Materials.\&. } \\
\text { Mechanics }\end{array}$ & $\begin{array}{c}\text { Circuits.\&. } \\
\text { Instrumentation }\end{array}$ & Systems & \\
\hline & & & $\begin{array}{c}\text { Entrepreneurial. } \\
\text { Engineering }\end{array}$ & $\begin{array}{l}\text { Engineering. } \\
\text { Project. } \\
\text { Management }\end{array}$ & Technical.Elective & Technical.Elective & Technical.Elective \\
\hline
\end{tabular}

Through the sophomore design experience, students are empowered as representatives of JMU and Madison Engineering. In order to prepare students for this responsibility, students are introduced to their team, their class, and their academic cohort as a broader system. Students are taught to understand that their decisions as an engineer not only affect the company that they work for (the University and the Department), but that those decisions also affect the broader community and the global system (the client and the client's family). Initially, students focus on understanding who they are and what they value as an individual before building relationships amongst their team as well as with the project's client.

Through the course, students learn to apply the engineering design process toward creating this custom designed human-powered vehicle. Students learn the challenge of collecting real customer needs and must accept that those customer needs are not absolute, which is a challenge and a surprise to most. Students learn to interface with partners. Students underestimate the challenge of managing an engineering team during the fall when on a team of four and then struggle with the management of a team of nine in the spring. Students learn to explore the solution space, analyze designs, and produce prototypes in an iterative process. Students are faced with completing a prototype on time for delivery to a client, and are rewarded with the satisfaction of seeing another person's life positively impacted through their engineering work.

One or two rising junior students are hired each summer to tear down the final prototypes, redesign any parts or systems requiring redesign, and reconstruct a single final prototype that can be delivered to the client. These students are mentored through this redesign process by the 
course's faculty lead, and at the completion of the summer, these students are offered the opportunity to be a teaching assistant (TA) for the course where they assist with student design issues, studio monitoring, grading, and lab activities during the next academic year's sophomore experience.

\section{Stakeholders \& Partnerships}

Stakeholders of the Madison Engineering sophomore design experience include the students enrolled in the program, the faculty members who teach the course sequence as well as those who receive the alumni of the course sequence, student teaching assistants (TAs) and interns, the Madison Engineering Department and JMU, the client, and the client's family and friends.

Partnerships include a professor of kinesiology, the Overcoming Barriers program, a local bike mechanic/builder, the university machinist, and the engineering department's lab manager.

\section{Relationships}

Relationships between all partners and stakeholders are foundational to the success of the sophomore design experience. Consequently, each year, at the start of the project, class time and homework assignments stress the importance of understanding yourself and your team before trying to understand your client. The goal is to create community among teams and classes. Further, through built in points where calculated failure can occur, the importance of getting to know your client before showing up with a measuring tape and detailed questions is demonstrated. With 90 to 110 students, students must learn to not compete toward completion of a final prototype, but rather, to work together for common success. They must critique each other, share ideas with each other, and share knowledge with each other, and to ensure that this goal is met and maintained, time is set aside for these activities throughout the sophomore design experience. It is through this process that students slowly begin to understand that the project is not a competition for completion, but rather, a team journey that benefits others and themselves.

Students are first introduced to the client through a video and a guest lecture given by a professor of kinesiology, who himself has cerebral palsy. Students learn about what it means to have cerebral palsy and how it affects him and the client both daily and long term. The professor of kinesiology, who also was the client from the project's first year, understands the process, has personal insight into the challenges that the students will face, and can provide initial guidance toward students' research activities. This meeting starts the information gathering and conceptual design phases of the process for the engineering students.

As students move through the engineering design process (following the Dym and Little Engineering Design ${ }^{8}$ text book from conceptual design to beta prototype), students must not only learn about the client, but also about human-powered vehicle design and construction. A local bike mechanic/builder helps the students learn about bicycle subsystems and functionality as well as how to use the tools in a department-provided bike toolbox. Additionally, the local bike mechanic/builder holds office hours in the studio from conceptual design through beta prototype to help the students refine, detail, and construct their ideas. Students learn to trust and rely on this partnership as a valuable resource throughout the academic year. Without this partnership, the program could not be successful.

Similar to the partnership with the local bike mechanic/builder, students work with the University machinist and the engineering lab manager to construct their designs. Through these partnerships, students complete the tool and safety training necessary to work with engineering fabrication and machining equipment. Students take engineering drawings and raw materials to 
the University machinist to have parts fabricated. The engineering lab manager is a certified welder and performs all project welding. It is because of these long term relationships that we can ensure honest and consistent information channels are maintained throughout the year.

\section{Channels}

Channels of communication to facilitate the sophomore design experience are varied and occur throughout the calendar year. Correspondence with a potential client and the course faculty lead begins over the summer and leads to a face-to-face meeting in August to discuss the details of the sophomore design project and contract. Beginning one week before the start of the fall semester course, coordination among stakeholders and partners occurs through email from the course faculty lead. Initial emails set times for the stakeholders and partners to attend class and meet the students in the first semester. Subsequent emails maintain communications and ensure the project is progressing.

Channels of communication that directly involve the students are maintained through face-toface meetings, class time, course management system, and other electronic notifications such as email. A summary of the communication channels between the stakeholders, partners, and the students is given in Table 2 .

TABLE 2

Summary OF COMMUNiCATION CHANNELS BETwEEN STUdENTS AND STAKEHOLDERS AND PARTNERS.

\begin{tabular}{|c|c|c|c|c|}
\hline & Email & $\begin{array}{c}\text { Course Management } \\
\text { System }\end{array}$ & Class Time & Face-to-Face Meetings \\
\hline $\begin{array}{c}\text { Engineering } \\
\text { Professors }\end{array}$ & As needed & Weekly announcements & Weekly announcements & $\begin{array}{c}\text { Students attend office } \\
\text { hours }\end{array}$ \\
\hline $\begin{array}{l}\text { Kinesiology } \\
\text { Professor }\end{array}$ & $\begin{array}{l}\text { Follow up } \\
\text { questions } \\
\text { throughout } \\
\text { project }\end{array}$ & $\begin{array}{l}\text { Presentation feedback is } \\
\text { shared with all students }\end{array}$ & $\begin{array}{c}\text { Introduced to students in } \\
\text { Sophomore Design 1; } \\
\text { attends student } \\
\text { presentations }\end{array}$ & $\begin{array}{l}\text { Follow up questions } \\
\text { throughout semester }\end{array}$ \\
\hline $\begin{array}{l}\text { Local bike } \\
\text { mechanic/ } \\
\text { builder }\end{array}$ & $\begin{array}{l}\text { Follow up } \\
\text { questions } \\
\text { throughout } \\
\text { project }\end{array}$ & $\begin{array}{l}\text { Presentation feedback is } \\
\text { shared with all students }\end{array}$ & $\begin{array}{l}\text { Introduced to students in } \\
\text { Sophomore Design 1; } \\
\text { attends student } \\
\text { presentations }\end{array}$ & $\begin{array}{c}\text { Students attend office } \\
\text { hours }\end{array}$ \\
\hline $\begin{array}{l}\text { University } \\
\text { Machinist }\end{array}$ & & $\begin{array}{l}\text { Reminders about signing } \\
\text { up for tools training }\end{array}$ & $\begin{array}{l}\text { Introduced to students in } \\
\text { Sophomore Design 1; } \\
\text { discusses safety and tools } \\
\text { training }\end{array}$ & $\begin{array}{l}\text { Twice in the machine } \\
\text { shop during Sophomore } \\
\text { Design 1; As needed in } \\
\text { Sophomore Design } 2\end{array}$ \\
\hline $\begin{array}{c}\text { Engineering } \\
\text { Lab } \\
\text { Manager }\end{array}$ & & $\begin{array}{l}\text { Reminders about } \\
\text { returning bike tool boxes }\end{array}$ & $\begin{array}{l}\text { Introduced to students in } \\
\text { Sophomore Design 1; } \\
\text { discusses safety and bike } \\
\text { toolboxes }\end{array}$ & $\begin{array}{l}\text { Twice in the design } \\
\text { studio to check out bike } \\
\text { toolboxes during } \\
\text { Sophomore Design } 2\end{array}$ \\
\hline Client & & $\begin{array}{l}\text { Presentation feedback is } \\
\text { shared with all students }\end{array}$ & $\begin{array}{l}\text { Attends student } \\
\text { presentations }\end{array}$ & $\begin{array}{l}\text { Weekly observations } \\
\text { and interactions }\end{array}$ \\
\hline
\end{tabular}

Face-to-face is the primary form of communication for the students with the stakeholders and project partners. Students not only build relationships that allow them to meet the requirements of the course, but it also helps them to recognize the interconnectedness of stakeholders and partners in the project and how they play a key role in the overall success of the project. The 
personal interaction helps to solidify the connections in the systems view of the project, which is designed into the key activities of the course.

\section{Key Activities}

The key activities required to conduct the courses associated with the sophomore design experience fall into three categories-administrative, instructional, and client-which are managed by a course faculty lead. This lead faculty member manages the syllabi for the two courses; prepares all course lectures, labs, activities, and assignments; coordinates guest lectures for the classes; coordinates the client availability; manages the seminar/studio lab space dedicated to the courses; and oversees tool trainings necessary to meet Department safety policies. The following sub-sections provide descriptions of these three key activities.

\section{Key Activities: Administrative}

Each summer, between June and August, the course faculty lead works with the kinesiology professor to identify a client for the sophomore design experience. This process has varied from year-to-year from reaching out to prior Overcoming Barriers participants to potential clients reaching out to the faculty and staff in either Engineering or Kinesiology. Once a client is selected, the client (or their legal guardian) are asked to sign contracts with both Overcoming Barriers and Madison Engineering; this starts the process of integrating the client into the course and the design process.

Scheduling course partners happens each semester during the first week of classes. For the fall semester, the course faculty lead coordinates with kinesiology professor, the university machinist, and the bike machinist/builder for guest lectures, class activities, and homework assignments. The kinesiology professor typically visits during the third week of classes to help with client introduction. The kinesiology professor then coordinates on-campus hours for the client and the client's family. This information is passed back through the faculty lead to the students via the course management software. During the fourth week, the university machinist visits the classes and introduces the safety policies associated with fabrication spaces. Students are also introduced to mill and lathe training assignments which serve as the gateway to the University's apprentice program. During the sixth week of classes, students are introduced to the local bike machinist and builder as he leads through students through a bike fitting workshop. The local bike machinist and builder also returns during week nine to lead the students through bike tool training and a bike mechanics workshop.

At the start of the spring semester, the course faculty lead must coordinate with the kinesiology professor, the bike machinist/builder, and the engineering lab manager. Coordination in the spring is less about creating structured learning environments, and more about ensuring safe exploratory environments where the students can prototype, receive feedback, and iterate. Coordination with the kinesiology professor is to ensure that the client and the client's family will again be available through the semester so that students can meet with the client, ask questions, demonstrate and trial simple prototype designs. Coordination with the engineering lab manager is about ensuring student TAs, trained on all available equipment, are in the lab spaces during afternoons and evenings through the spring semester. Student TAs check to make sure each student has passed safety trainings, make sure safety rules are followed, and check out tools required to build prototype designs. The bike machinist/builder holds office hours in the studio, so his hours must be posted and updated as changes occur. 
Through the summer, one to two students are hired through the Madison Engineering Department to finalize the human-powered vehicle for final delivery. These students, under the supervision of the course faculty lead, identify the design solutions (from the beta prototypes) which worked best for the client to create a final human-powered vehicle. Beta prototypes are taken apart to salvage components, new components (such as sprockets, chain, and bearings) are purchased, and new custom-designed components are built with the help of the university machinist and the engineering lab manager. The final human-powered vehicle is typically complete between August and October of the following academic year, and all prior clients are invited back to campus for a formal hand-off event.

\section{Key Activities: Instructional}

Students' overarching task during the first semester is to follow the design process to generate numerous conceptual designs viable to meet the specific client needs. This process is largely directed at breaking down the potentially large and unstructured design project into more manageable and structured assignments. As a team of four-to-five, students apply the tools taught after individual and team-based, in-class exercises. Lectures progress from learning about the people involved in the project, including themselves and their teams, to how to design a product that meets a client's needs. Along this progression, assignments involve engaging the multiple channels of communication and within the first six weeks of the course the students have met all the stakeholders and partners. Students are first introduced to their client through a video. The kinesiology professor and the course faculty lead develop this video with the client and the client's family around mid-August. In the video, the client demonstrates their physical capabilities with respect to potential motions required to operate a human-powered vehicle. The course faculty lead edits and compresses the video for distribution through the course management system. At the conclusion of the first semester, the students present their conceptual designs during formal presentations to the client, and receive feedback such as, "Who thinks this stuff up anyway?" and "That's Impossible!" -reinforcing the idea that the students are designing for a client's needs, not their own.

At the start of the second semester, students are placed in new teams with eight-to-ten students in each and are asked to revisit all of the work performed during the prior semester and arrive at a new conceptual design iteration. Students are given two weeks and must present their results in a formal oral presentation to a panel of faculty members from the Madison Engineering Department. To move the students from conceptual design toward a final prototype, students must individually draw (by hand and using solid modeling software) one component of their design as well as create a physical proof-of-concept for one subsystem on their design followed by analytical analysis. Analysis includes material selection, weight and center of mass calculations, and force approximations under static loading. This integration of Materials \& Mechanics as well as Statics \& Dynamics coursework into engineering design begins to teach students that engineering design and engineering science are co-dependent in all engineering projects.

Through physical and analytical modeling, students begin to understand the limitations of "real" designs; in other words, students begin to transition from conceptual design to detailed design. To reinforce the concept of "real" design limitations, the students are taught to complete a qualitative life cycle impact assessment. Results of this research are tabulated and included in the students final design reports. Regular interaction with the client throughout the design process is built into assignments by requiring feedback to be documented and included. 
Both the fall and spring semesters conclude with presentations and the deliverables outlined in Table 3. During the final week of classes in the fall semester, students give a formal presentation discussing their conceptual designs; all stakeholders and partners who participated through the semester are invited back to class for these presentations. In the spring, students present their beta prototype. Formal beta presentations are closed to only faculty and students. A public exposition later provides a venue for all partners and stakeholders to see the student's creations. Each year, the client is invited to the public expo in the spring to ride each student team's final beta prototype. Syllabi are provided in the Appendices provide a week-by-week breakdown of all course activities.

TABLE 3

Deliverable Breakdown For The Sophomore Design Course Sequence.

\begin{tabular}{|c|c|c|c|}
\hline Semester & Fall 2013 & Spring 2014 & Summer 2014 \\
\hline Course & Sophomore Design 1 & Sophomore Design 2 & N/A \\
\hline Student Composition & Teams of 4-5 students & Teams of 8-10 students & 2 Student Interns \\
\hline Final Deliverable & Conceptual Design & Physical Prototype & Final Physical Design \\
\hline $\begin{array}{c}\text { Quantity of Final } \\
\text { Deliverable Across All } \\
\text { Sections }\end{array}$ & 28 & 9 & 1 \\
\hline
\end{tabular}

\section{Key Activities: Client}

The client, when joining the project, agrees via a contract developed in partnership with University Legal Services to work with the Engineering Department and the sophomore design students for the duration of the project - one-to-one and half calendar years. The contract further outlines that the stated purpose of the project is to create a suitable custom designed humanpowered vehicle, and if the project results in a suitable vehicle, at the end of the project, the vehicle becomes the property of client, and client agrees that it will accept the vehicle as is, with no warranties, guarantees, or promises concerning its operation, fitness, or safety. The client or the client's legal guardian is not charged for the cost of the materials, time, or design of the vehicle. Rather, the client agrees to be on campus for regular scheduled meetings with the students so that the students can interact with the client throughout the project.

Each year, the client agrees to be available a couple days through the week to interact with the students. To maximize the client's time, the student is enrolled in the kinesiology professor's Overcoming Barriers program, a physical activity mentoring program for individuals with disabilities. Through Overcoming Barriers, ${ }^{9}$ the client works with the kinesiology professor and his kinesiology/physical education students to develop an individualized workout program that develops the client's motor skills and health-related physical fitness in preparation for delivery of the human-powered vehicle.

Through the year-long project, a relationship is built each year between the client, the student mentor who works one-on-one with the client, the client's parents, and the engineering students. The kinesiology student mentor is the link between the client's improvements in their physical fitness program and the Engineering students understanding of those needs, abilities, or improvements. This relationship, like the one formed between students and the local bike mechanic/builder, is absolutely critical to the success of the program. 


\section{Resources}

The four key resources required of the sophomore design experience are time, space, materials, and funding.

Funding of $\$ 400$ is provided to each of the nine sophomore design teams each spring semester to cover material costs. Additionally, students are provided with dedicated studio space including storage cabinets, tools, and recycled materials (saved from prior years). Further offsetting material costs, each summer, bicycles are transferred from University surplus to the sophomore design studio. These bicycles, left behind by JMU students become the raw bicycle components for each year's human-powered vehicle project. Engineering students learn bicycle mechanics with these bicycles and then tear them down to build their own designs. Components purchased each year, still usable in later years, are categorized and stored in cabinets for future use.

Assisting with the process of sorting bicycles and prior human-powered vehicle components, along with trying to organize the general disarray that remains of the studio following each year's build, are undergraduate TAs. Each year, Madison Engineering provides student leadership opportunities through funded TAs and interns. Two upperclassmen are given the opportunity to mentor sophomores through their design experience as teaching assistants. The TAs perform typical duties such as grading, but also hold office hours in the studio space to assist with the design and construction of the human powered vehicles. At the end of the project, one-to-two sophomores who recently completed the sophomore design experience are given an internship opportunity with Madison Engineering to refine the client's vehicle into a final deliverable.

Dedicated flexible studio space, pictured in Figure 3, provides a 1,900 $\mathrm{ft}^{2}$ area where the sophomore engineering students can perform conceptual design activities in the fall and physical design activities "dirty work" in the spring. The space is equipped with student cabinets (each containing three toolboxes - two with mechanics tools and one with bike tools), equipment cabinets (containing recycled bike components, tool cabinets (containing powered hand tools), ten height adjustable tables, two drill presses and one band saw, one video projection system, and two CAD workstations. Student teams are each issued a cabinet key allowing them free use of the hand tools as well as team storage space.
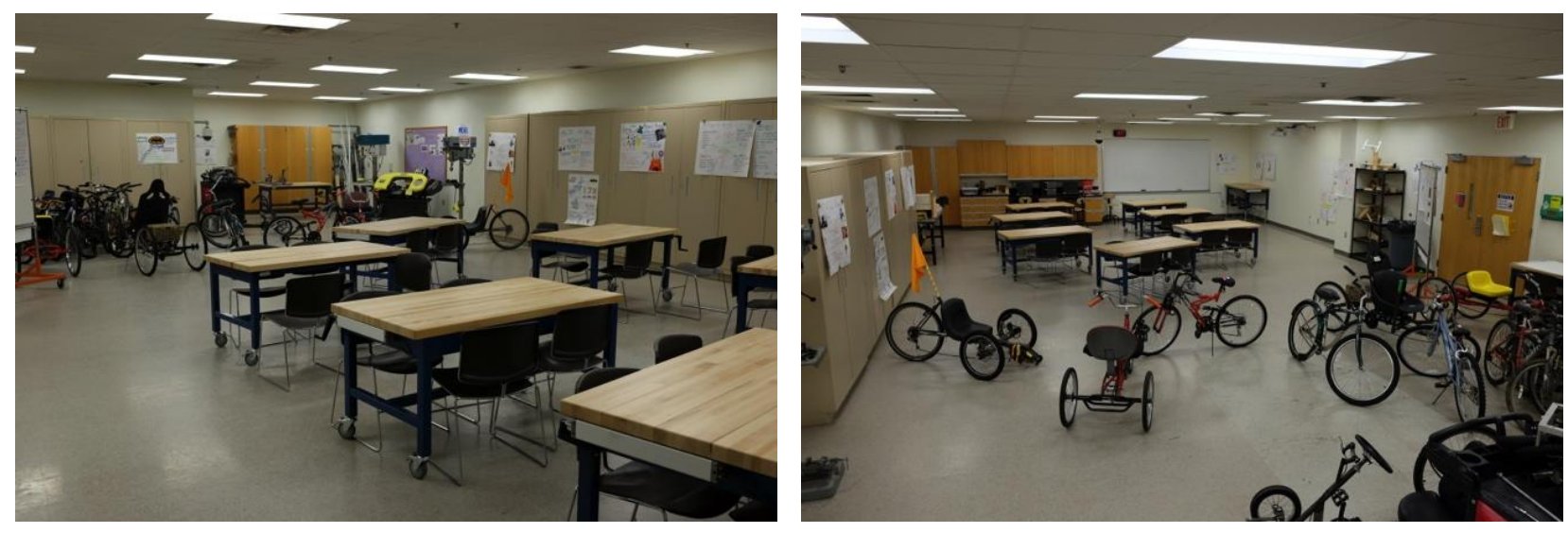

FIGURE 3

FLEXIBLE STUDIO SPACE DEDICATED TO THE SOPHOMORE DESIGN EXPERIENCE. 
During the fall semester, all equipment and tools remained locked in cabinets such that the room can be used freely by the students for conceptual design work. Once spring semester begins, the room transitions to dirty space; the students are to wear proper personal protective equipment, and TA hours are scheduled when students can use powered hand tools, drill presses, and the band saw. The room supports approximately $2 / 3$ of the sophomore students, but any given time, there might be 3 or 4 teams representing $1 / 3$ to $1 / 2$ of the total sophomore student cohort. Outside of the specified TA hours, the room is open to all students.

Mentorship of the students goes beyond other students, facilities, and faculty. Mentoring the students in this course incorporates the university machinist, Engineering's lab manager, and the local bicycle builder/mechanic who are critical to the overarching sophomore experience teaching team. To facilitate this process, Madison Engineering has formalized funding to compensate the local bicycle builder/mechanic for his help with the project. This formalization has allowed the local bicycle mechanic/builder to obtain swipe access to the flexible studio space and has provided him with JMU email access. Further, the university machinist and the engineering lab manager have been gracious with their time answering students questions, providing design-for-fabrication guidance, helping with machining of student parts, and performing all required welding. Without the knowledge and time that key stakeholders and partnerships provide to the project, it would be impossible for the project to be successful.

\section{Value Streams}

Value streams are separated into two categories - costs and outlays and returns - and aim to capture and relate the value going into and the value coming out of a project, respectively. The value streams of the sophomore design experience are directly correlated to the resources and relationships associated with the sophomore design course sequence. The following two subsections provide descriptions of the two types of value streams.

\section{Value Streams: Costs and Outlays}

The costs and outlays to conduct the sophomore design experience include funding to operate the flexible studio space (student lab fees), funding for tools (student lab fees), funding for safety and manufacturing training (departmental budget), funding for nine design teams (\$400 per team from student lab fees), funding for the local bicycle mechanic/builder ( $\$ 3 \mathrm{~K}$ per year from student lab fees), funding for a summer intern ( $\$ 2 \mathrm{~K}$ per student from departmental budget), funding for TAs ( $\$ 8$ per hour from departmental budget), client time, student time, and instructor time. Student tuition and fees offset most of the outlays.

Giving students an authentic experience aligned with the mission, vision, and values of the department and University that also gives the client real return on investment, is a direct cost toward instructor time. During Engineering Design I, instructors spend a great deal of time building and coordinating the relationships (client, client family, local bicycle mechanic and builder, TAs, machine shop) for the project. During Engineering Design II, instructors spend their time maintaining relationships and spending time in the studio with student teams outside of class.

The number of students involved in the project presents a challenge to the students as well as the other stakeholders in the project. The machine shop must put outside University jobs on hold during the fall semester when student mill and lathe training is taking place. To schedule each students mill and lathe training, students visit the shop during the scheduling window and select an open time. Additionally, the client and the client's family frequently become overwhelmed 
during meeting times causing student questions to go unanswered until a later meeting, and students may also interfere with the Overcoming Barriers training and be asked to leave. Balancing these tradeoffs, while often challenging, has not been impossible. For example with respect to mill and lathe training, no makeup times are permitted, and if a student misses the scheduling window, they loose the opportunity to complete the training for course points. Through conversations with partners and stakeholders, we have worked to set expectations and develop schedules to accommodate 100+ engineering sophomores.

\section{Value Streams: Returns}

The returns associated with the sophomore design experience are many, and include student learning, student personal growth, a custom product for the client, TA leadership experience, a stronger connection between the community and the University, Madison Engineering departmental reputation, faculty publications, stakeholder personal satisfaction and engagement, and machine shop apprentices.

The primary, tangible return of the sophomore design experience is the custom humanpowered vehicle for the client in exchange for their time. A final product has been completed for the client each year, which has been instrumental in the success of the annual project as well as lead to other tangible returns. Other tangible returns include number of scholarly publications for faculty, ${ }^{1-4,10}$ media coverage to promote the Madison Engineering program, ${ }^{11-15}$ recognition in the University strategic mission, ${ }^{16}$ and number of apprentices (8+) for the machine shop. All other returns are considered intangible, but essential for the overall success of the design experience.

Engagement and satisfaction by all stakeholders is important. When faculty are engaged, they find working with the students and the client rewarding. The same can be said for the local bicycle mechanic/builder, the university machinist, and the engineering lab manager. Facilitating student learning is the reason the project exists, but it also impacts them personally. In end of year project reports, students comment in their reflection statements on how the project has been a life changing experience or opened their minds to how engineers can make an impact. The undergraduates TAs are empowered to lead their peers, which also leads to personal growth and professional development. Ultimately, engagement and satisfaction by all stakeholders builds the reputation of the Madison Engineering program.

\section{ASSESSMENT}

Course assessment occurs at four levels: assignments, course, course sequence, and programmatic. While course and programmatic are a part of the broader departmental assessment plan, assignment and course sequence have generally been carried out by the faculty instructors teaching this course and have been a part of their scholarship portfolios. Exemplar of previously published summaries of both course sequence-level and assignment-level assessments follow. It should be noted that assessment has not yet focused on individual clients or the community of recipients; this assessment, however, has been discussed as the next step toward understanding broader impacts related to the project. 


\section{Course Sequence-Level Assessment}

At the course sequence-level, prior assessment activities have concentrated on students' perceived learning outcomes and learning gains as a result of participating in the sophomore design problem based service learning (PBSL) experience. Two questions focused the research: 1. What are engineering students' cognitive and affective learning outcomes as a result of participating in a two-semester PBSL sophomore design project? and 2. What are engineering students' cognitive and affective learning outcome gains as a result of participating in a twosemester PBSL sophomore design project? ${ }^{4}$

The study performed used a mixed-methods approach with data collection involving the use of the NESLOS instrument as well as several open-ended questions to gain deeper insight into students' learning outcomes. ${ }^{4}$ Gains were identified across all constructs of the NESLOS instrument with the highest gains in Big Picture Skills, Communication Skills, Personal Development, Lifelong Learning, and Ethical and Societal Awareness. ${ }^{4}$ From the thematically analyzed qualitative data, Design Tools \& Methods, Teamwork, and Real-world Application were the themes most mentioned among the student respondents. ${ }^{4}$

The goal of this paper was to show how qualitative and quantitative data could be used to assess student learning and learning gains. The results, however, have informed decisions related to how design tools should be taught and which course themes need stronger emphasis throughout the sophomore design experience.

\section{Assignment-Level Assessment}

At the assignment-level, prior assessment activities have focused on students' ability to apply particular engineering design tools and methodologies toward their course projects. For example, an approach for scaffolding the process of functional model generation was trialed experimentally to see if students were better able to generate functional models when following the scaffolding process. ${ }^{17}$ In the study, students were divided into four groups based on class section.

It was found that students provided a packet of quality examples performed as well as those students provided the scaffolding approach, while those students with only the textbook and lecture notes performed at a standard deviation less than those with the examples or scaffolding approach. ${ }^{17}$ Studies such as this assignment-level study on functional modeling provide validation that course materials developed for the sophomore design experience do in fact actually "work" as intended and that students are in fact learning to apply concepts taught in class to their course project.

\section{LESSONS LEARNED}

Our journey over the past five years has lead to the well-organized and coordinated course described in this paper. Many lessons over those five years have been learned with respect to the sophomore design experience. The following list highlights the lessons learned that are transferable to other institutions:

- People and place must be aligned for engagement outside the classroom. For example, when people and place are misaligned, the client is not engaging the students and visa 
versa. All time is spent trying to keep the project moving forward and building the relationships rather than maintaining them.

- Partnerships with local experts are necessary. One or two faculty members will not have all the expertise needed, or the availability to work one-on-one with all the students and the client. The added benefit is that students get to interact with stakeholders outside the department and/or University.

- Need to regularly bring the client to the campus. Bringing the client to where the students are lowers the hurdle for them to engage with the client as not all have access to appropriate transportation. Also, regular weekly meeting times allow students to plan ahead for client meetings.

- Client and client's family must to be interested in the opportunity and willing to participate for the entire year. Ensure that clients do not find the project timeframe daunting and the scope unrealizable. Rather, seek out clients that find the project exciting and a great opportunity.

- Requires a lot of faculty and client time. Faculty must be willing to spend out of class time with the client, which is crucial for relationship building. Faculty must also be willing to support students during the build in the second semester by showing up to the lab in the evening. Spending time with the students in the lab ensures that we are all in this project together and further motivates them to complete a working beta prototype by the end of the semester.

- Students need to recognize themselves as a stakeholder beyond grades. Activities and discussions should be in place so students understand that their decisions as an engineer not only affect the company that they work for (the University and the Department), but that those decisions also affect the broader community and the global system (the client and the client's family).

- Space is essential and includes: team storage space, seminar space, conceptual design space, dirty making space, and testing space. It is too much of a burden to expect the students to provide this resource, especially with large teams. By providing the necessary spaces, the students can focus their efforts on the design rather than where to house everything.

\section{Concluding Thoughts}

The choice to offer and maintain a mandatory year-long service learning project at the sophomore-level cannot be a simple proposition. It takes significant time and resources as demonstrated by the exercise of completing the Learning Through Service Program Model Blueprint. Perhaps the most enlightening aspect of this process is the direct impact people have on the success to the project. The impactful players range from the clients and their families, subject matter experts, former and current course instructors, staff, and administrators, who are willing to share their time. Without the dedication of these people involved, the project simply could not be successful. Consequently, the most important takeaway, is that partnerships, stakeholders, and relationships should not be left to chance. Time and care must be put into each and every year to ensure that all components are in place so that each cohort of students receives learning and training as good or better than prior cohorts such that they are prepared for success in all future engineering courses. 


\section{ACKNOWLEDGEMENTS}

Many collective and collaborative efforts have gone into the development and creation of the Sophomore Design Experience, and consequently, the authors would like to acknowledge the faculty, staff, and administration of the Madison Engineering Department and the College of Integrated Science and Engineering. Also, the author's would like to acknowledge the founding faculty members for the Sophomore Design Experience Dr. Olga Pierrakos and Dr. Eric Pappas; Mr. Les Welch, local bike expert, mechanic, and builder; and all prior client's and their families for being so generous with their time and their willingness to work with our students.

\section{REFERENCES}

${ }^{1 .}$ Nagel, R.L., O. Pierrakos, E. Pappas, and J.K. Nagel. "On a Client-Centered, Sophomore Design Course Sequence." In 119th ASEE Annual Conference \& Exposition. San Antonio, TX: ASEE, 2012.

2. Nagel, J, R. Nagel, E. Pappas, and O. Pierrakos. "Integration of a Client-Based Design Project into the Sophomore Year." In ASME 2012 International Design Engineering Technical Conferences. Chicago, IL: ASME, 2012.

3. Pierrakos, O., and E. Pappas. "Assessing Students' Learning Outcomes During a Complex and RealWorld Problem-Based Service Learning (PBSL) Project in a Sophomore Engineering Design Course." In ASEE Annual Conference \& Exposition. Louisville, KY, 2010.

4. Pierrakos, O., R. Nagel, E. Pappas, J. Nagel, T. Moran, E. Barrella, and M. Panzio. "A Mixed-Methods Study of Cognitive and Affective Learning During a Sophomore Design Problem-Based Service Learning Experience." International Journal for Service Learning in Engineering Special Edition, no. Fall (2014): $1-28$.

${ }^{5 .}$ Bielefeldt, Angela R., K. Paterson, C. Swan, O. Pierrakos, D.O. Kazmer, and A. Soisson. "Spectra of Learning through Service Programs." In 120th ASEE Annual Conference and Exposition. Atlanta, CA: ASEE, 2013.

6. EPICS, EWB-USA, and EFELTS. "Integrating Design and Community Engagement within the Curriculum Workshop." http://www.conf.purdue.edu/landing_pages/epicsdesign/.

7. Osterwalder, Alexander, and Yves Pigneur. Business Model Generation. Hoboken, NJ: John Wiley \& Sons, Inc., 2010.

${ }^{8 .}$ Dym, C.L., and P. Little. Engineering Design: A Project-Based Introduction. Hoboken: John Wiley \& Sons, INC., 2009.

9. Dixon, Colleen. "Overcoming Barriers." Be the Change, Nov 26, 2012.

10. Pierrakos, O., E. Pappas, R.L. Nagel, and J.K. Nagel. "A New Vision for Engineering Design Instruction: On the Innovative Six Course Design Sequence of James Madison University." In 119th ASEE Annual Conference \& Exposition. San Antonio, TX, 2012. 
${ }^{11 .}$ Nagel, R. "Engineering Students and Faculty Design and Build a Unique Human-Powered Vehicle." 2011.

12. Chan, IJ. "Boy Overcomes Disability with Student-Built Bike." The Breeze, 2013.

13. WHSV Newsroom. "Jmu Student Builds Bike for Child with Disability." http://www.whsv.com/home/headlines/JMU-Student-Build-Bike-For-Child-With-Disability222027241.html.

14. Thomas, Loren. "Boy Gets a New Bike and a Boost in Confidence." The Charlottesville Newsplex, http://www.newsplex.com/home/headlines/Boy-Gets-a-New-Bike-and-a-Boost-in-Confidence222013841.html.

15. Farinholt, Austin. "Engineering Students Address Teen's Disability with Bicycle Design." James Madison University Office of Public Affairs, http://www.jmu.edu/news/madisonscholar/2011EngineeringBicycle.shtml.

16. James Madison University. "JMU's Strategic Plan." James Madison University, http://www.jmu.edu/jmuplans/jmu-strategic-plan/index.shtml.

${ }^{17 .}$ Nagel, R.L., M.R. Bohm, and J.S. Linsey. "A Study on Teaching Functional Modeling in a Sophomore Engineering Design Course." In 121st ASEE Annual Conference and Exposition. Indianapolis, IN: ASEE, 2014. 


\section{APPENDix 1: EngineERING DeSign 1 Syllabus}

\begin{tabular}{|c|c|}
\hline Credits and contact hours: & 2 Credits and 2 Contact Hours \\
\hline \multirow{3}{*}{$\underline{\text { Textbooks and materials: }}$} & $\begin{array}{l}\text { Dr. Robert Nagel } \\
\text { Dr. Jacquelyn Nagel } \\
\text { Dr. Kyle Gipson }\end{array}$ \\
\hline & Engineering Design, $3^{\text {rd }}$ Edition, Dym and Little, 2009 \\
\hline & Microsoft Office Applications (Word, Excel, and PowerPoint) \\
\hline Course Description: & $\begin{array}{l}\text { This course is the first of six courses in the engineering design sequence. This course } \\
\text { provides students with an overview of sustainable engineering design including history, } \\
\text { concepts, and practices; and an introduction to cognitive processes and interpersonal } \\
\text { communication skills that lead to effective problem solving, idea generation, and } \\
\text { decision making; and basic technical design skills. }\end{array}$ \\
\hline Prerequisites: & ENGR 112 - Introduction to Engineering \\
\hline Course Type: & Required \\
\hline
\end{tabular}

Specific course outcomes and the relation to ABET criteria are illustrated below.

\begin{tabular}{|l|l|}
\hline Course Outcomes & \multicolumn{1}{|c|}{$\begin{array}{c}\text { ABET } \\
\text { Outcomes }\end{array}$} \\
\hline Upon successful completion of this course, the student will be able to: & $\mathrm{c}$ \\
\hline Identify and describe the stages of the design process & $\mathrm{c}$ \\
\hline Describe and discuss creative engineering design practices & $\mathrm{c}$ \\
\hline Identify, describe, and discuss the customer needs which inform an engineered product & $\mathrm{c}$ \\
\hline Research and establish target specifications, functions, and constraints to describe the customer needs & $\mathrm{c}$ \\
\hline Generate multiple conceptual designs using manual and computational methods & $\mathrm{b}, \mathrm{c}$ \\
\hline $\begin{array}{l}\text { Explore, analyze, and evaluate conceptual designs using decision-making strategies, sustainability } \\
\text { principles, and customer needs }\end{array}$ & $\mathrm{c}, \mathrm{f}, \mathrm{h}$ \\
\hline Demonstrate a basic understanding of sustainability and ethical issues related to engineering design & $\mathrm{g}$ \\
\hline $\begin{array}{l}\text { Communicate a final design concept and the rational for its selection through both written and oral } \\
\text { presentation }\end{array}$ & $\mathrm{d}$ \\
\hline Work effectively in a team setting & $\mathrm{c}, \mathrm{d}, \mathrm{e}$ \\
\hline Demonstrate basic project management skills necessary to solve engineering design problems & \\
\hline
\end{tabular}

\section{Topics:}

1. Design and Systems Thinking

2. Team Building, Team Dynamics, Code of Conduct, Methods for Conducting Meetings

3. Engineering Ethics

4. Client Interviews, Customer Needs Identification

5. Sorting and Rank Ordering Customer Needs

6. Functional Analysis and Specification Identification

7. Concept Generation including: Design-by-Analogy, C-Sketch, and Morphological Matrices

8. Design Evaluation using Pugh Charts and Decision Matrices

9. Design Evaluation based on Function-Failure Analysis

10. Design Iteration 
International Journal for Service Learning in Engineering Special Edition, pp. 439-459, Fall 2014

ISSN 1555-9033

11. Lathe \& Mill Training

\begin{tabular}{|c|c|c|c|}
\hline $\begin{array}{l}\text { Week } \\
\quad \#\end{array}$ & In Class Lecture and/or Lab Activity & Reading & Homework \\
\hline 1 & $\begin{array}{l}\text { Introduction \& Vision for Course; Assign Teams; } \\
\text { What is Design? }\end{array}$ & Ch. 1 & $\begin{array}{l}\text { Design Assignment w/ Team Building } \\
\text { Activity }\end{array}$ \\
\hline 2 & Present Homework; Intro on Managing your Team & Ch. 2 & $\begin{array}{l}\text { Office Seating Assignment; Draft Code of } \\
\text { Conduct }\end{array}$ \\
\hline 3 & $\begin{array}{l}\text { Present Homework; Professor of Kinesiology } \\
\text { Visit; Introduce Project and Client through Video }\end{array}$ & Ch. 10 & Research Paper; Compile Take-Aways \\
\hline 4 & $\begin{array}{l}\text { University Machinist to Visit and Introduce } \\
\text { Machine Shop Safety; Knowing your Customer; } \\
\text { Customer Personas; Disability Exercise; Team } \\
\text { Management }\end{array}$ & Ch. 3 & $\begin{array}{l}\text { Create a Customer Persona; ALRT-C \& } \\
\text { Safety Quiz; Finalize Code of Conduct }\end{array}$ \\
\hline 5 & $\begin{array}{l}\text { Present Personas; Client Interviews; Customer } \\
\text { Needs; Ethics in Design }\end{array}$ & Ch. 12 & $\begin{array}{l}\text { Develop Customer Needs List; } \\
\text { Engineering Ethics Cases }\end{array}$ \\
\hline 6 & $\begin{array}{l}\text { Customer Speak vs. Engineering Speak; Bike } \\
\text { Sizing Discussion (Bike Mechanic/Builder Visit) }\end{array}$ & Ch. 4 & $\begin{array}{l}\text { Develop list of Target Specifications \& } \\
\text { Constraints }\end{array}$ \\
\hline 7 & Requirements: Functional Modeling \& Systems & & Develop Functional Model \\
\hline 8 & Midterm & & \\
\hline 9 & $\begin{array}{l}\text { Benchmarking; Bike Teardown Lab (Bike } \\
\text { Mechanic/Builder Visit) }\end{array}$ & & $\begin{array}{l}\text { Benchmarking Assignment; Refine } \\
\text { Functional Model, Target Specifications; } \\
\text { Constraints }\end{array}$ \\
\hline 10 & $\begin{array}{l}\text { Present Homework; Concept Generation (C- } \\
\text { Sketch, Morph Matrices, Brainstorming) }\end{array}$ & Ch. 5 & Concept Sketches and Descriptions \\
\hline 11 & $\begin{array}{l}\text { Concept Generation (C-Sketch, Morph Matrices, } \\
\text { Brainstorming) }\end{array}$ & & Concept Sketches and Descriptions \\
\hline 12 & $\begin{array}{l}\text { Design Evaluation (Pugh Charts, Decision } \\
\text { Matrices, Function-based Failure Analysis) }\end{array}$ & & $\begin{array}{l}\text { Pugh Chart and Decision Matrix, Failure } \\
\text { Analysis }\end{array}$ \\
\hline 13 & $\begin{array}{l}\text { Present Homework; Review \& Reflect; MAD(E) } \\
\text { Design Process Guide; Presentation Visuals }\end{array}$ & & $\begin{array}{l}\text { Presentation; Design Portfolio Assignment } \\
\& \text { Reflection }\end{array}$ \\
\hline 14 & \multicolumn{3}{|l|}{ Thanksgiving Week-No Class } \\
\hline 15 & Presentations to Stakeholders \& Partners & Ch. 9 & \\
\hline 16 & \multicolumn{3}{|l|}{ Final Exam Week } \\
\hline
\end{tabular}

\section{Method of Evaluation:}

- Individual Assignments, Assigned Throughout, $15 \%$ of Grade

- Team/Project Assignments, Assigned Throughout, $15 \%$ of Grade

- Midterm Exam, Week 8, 30\% of Grade

- Final Exam, Week 16, 30\% of Grade

- In-class Participation, Throughout, 5\% of Grade

- Team Participation, Self \& Peer Evaluation on Midterm and Final Exams, 5\% of Grade 


\section{APPENDix 2: EnginEERING DeSign 2 Syllabus}

\begin{tabular}{|c|c|}
\hline Credits and contact hours: & 2 Credit and 2 Contact Hours \\
\hline \multirow{3}{*}{ Textbooks and materials: } & $\begin{array}{l}\text { Dr. Robert Nagel } \\
\text { Dr. Jacquelyn Nagel }\end{array}$ \\
\hline & Engineering Design, $3^{\text {rd }}$ Edition, Dym and Little, 2009 \\
\hline & Microsoft Office (Word, Excel, and PowerPoint), Solid Works \\
\hline Course Description: & $\begin{array}{l}\text { This course is the second course in the engineering design sequence. This course } \\
\text { provides instruction in sustainable engineering design concepts and hands-on practice; } \\
\text { individual cognitive processes, thinking and communication skills, and decision making; } \\
\text { introduction to sustainability contexts (environmental, social, economic, and technical); } \\
\text { and technical project design skills. }\end{array}$ \\
\hline Prerequisites: & ENGR 231 - Engineering Design I \\
\hline Course Type: & Required \\
\hline
\end{tabular}

Specific course outcomes and the relation to ABET criteria are illustrated below.

\begin{tabular}{|l|l|}
\hline Course Outcomes & \multicolumn{1}{|c|}{$\begin{array}{c}\text { ABET } \\
\text { Outcomes }\end{array}$} \\
\hline Upon successful completion of this course, the student will be able to: & $\mathrm{c}$ \\
\hline Identify and describe the stages of the design process & $\mathrm{c}$ \\
\hline Describe and discuss creative engineering design practices & $\mathrm{c}, \mathrm{f}, \mathrm{h}$ \\
\hline Demonstrate a basic understanding of sustainability and ethical issues related to engineering design & $\mathrm{c}$ \\
\hline Construct and assess designs using elementary physical prototypes & $\mathrm{c}$ \\
\hline Perform basic tool skills needed to complete design projects & $\mathrm{c}, \mathrm{k}$ \\
\hline $\begin{array}{l}\text { Create a system-level \& detailed product design including (geometric layout, bill-of-materials, } \\
\text { engineering drawings, and material selection) }\end{array}$ & $\mathrm{c}, \mathrm{b}$ \\
\hline Create and follow a plan for testing and refinement based on design prototypes & $\mathrm{g}$ \\
\hline $\begin{array}{l}\text { Communicate a final design and the rational behind the design through both written and oral } \\
\text { presentation }\end{array}$ & $\mathrm{d}$ \\
\hline Work effectively in a team setting & $\mathrm{c}, \mathrm{d}, \mathrm{e}$ \\
\hline Demonstrate basic project management skills necessary to solve engineering design problems & \\
\hline
\end{tabular}

\section{Topics:}

1. Proof-of-Concept Prototypes, Alpha Prototypes, Beta Prototypes

2. System Level Design: Geometric Layout

3. Detailed Design: Engineering Drawings

4. Detailed Design: Mass and Center-of-Mass Analysis

5. Detailed Design: Force Analysis in Frames

6. Detailed Design: Material and Component Selection

7. Detailed Design: Bill of Materials

8. Testing and Refinement Plans

9. Sustainability Analysis 
International Journal for Service Learning in Engineering Special Edition, pp. 439-459, Fall 2014

ISSN 1555-9033

\begin{tabular}{|c|l|l|l|}
\hline $\begin{array}{c}\text { Week } \\
\#\end{array}$ & In Class Lecture and/or Lab Activity & Reading & Homework \\
\hline 1 & $\begin{array}{l}\text { Introduction \& Vision for Course; 231 Slide Critique; } \\
\text { Team Roles Discussion; Assign New Project Teams }\end{array}$ & Ch. 1-5 & Project Redesign Report; Presentation \\
\hline 2 & $\begin{array}{l}\text { Empathy Exercise at Godwin Hall with Professor of } \\
\text { Kinesiology }\end{array}$ & Install Solid Works \\
\hline 3 & $\begin{array}{l}\text { Redesign Presentations; Engineering Drawings, Drafting; } \\
\text { Prototyping }\end{array}$ & Ch. 7-8 & $\begin{array}{l}\text { Bike Component Drawing, Proof-of- } \\
\text { Concept Prototype }\end{array}$ \\
\hline 4 & $\begin{array}{l}\text { Prototype Presentation, Engineering Drawings, Bill of } \\
\text { Materials, Cost Analysis }\end{array}$ & $\begin{array}{l}\text { Component Engineering Drawing, } \\
\text { Bill of Materials }\end{array}$ \\
\hline 5 & Solid Works (Modules Posted to Canvas) & Bike Component Solid Model \\
\hline 6 & $\begin{array}{l}\text { Prototype Presentation, Engineering Drawings in Solid } \\
\text { Works }\end{array}$ & \multicolumn{2}{|l|}{} \\
\hline 7 & Material Selection, Mass \& Center of Mass Analysis & Ch. 6 & $\begin{array}{l}\text { Mass \& Center of Mass Analysis } \\
\text { Assignments }\end{array}$ \\
\hline 8 & Midterm & \multicolumn{2}{|l|}{} \\
\hline 9 & Spring Break-No Class & Ch. 6 & $\begin{array}{l}\text { Frame \& Stress Assignment; Bike } \\
\text { Frame Analysis }\end{array}$ \\
\hline 10 & Frame Analysis \& Intro to Stress Analysis & Ch. 6 & Mass \& Center of Mass Analysis \\
\hline 11 & $\begin{array}{l}\text { Design Reliability, Sustainability, Life Cycle Analysis } \\
\text { The Impact of Your Choices) }\end{array}$ & Alpha Prototype Update Memo \\
\hline 12 & Work Period / Consulting & Alpha Prototype Update Memo \\
\hline 13 & Alpha Prototype Due! Demonstration \& Presentations & & Testing \& Refinement Assignment \\
\hline 14 & Testing, Refinement, and Deign Validation & & Beta Prototype Update Memo \\
\hline 15 & Work Period / Consulting & Bpdate Memo \\
\hline 16 & Beta Prototype Due! Demonstration \& Presentations & & \multicolumn{2}{|l|}{} \\
\hline 17 & Final Exam Week & & \\
\hline & & & \\
\hline
\end{tabular}

\section{Method of Evaluation:}

- Individual Assignments, Assigned Throughout, $15 \%$ of Grade

- Team/Project Assignments, Assigned Throughout, $15 \%$ of Grade

- Midterm Exam, Week 8,30\% of Grade

- Final Exam, Week 16,30\% of Grade

- In-class Participation, Throughout, 5\% of Grade

- Team Participation, Self \& Peer Evaluation on Midterm and Final Exams, 5\% of Grade 